\title{
The Photo-Text in the Mussolini Era
}

\author{
By Carla Rossetti*
}

In the 1930s, Fascism's Mythopoeia found in propaganda photobooks a comfortable space in which to configure itself. The layout of the photobooks draws on the experiments carried out by the editors of "Campo Grafico" [1933 - 1939] and by eclectic personalities like Guido Modiano; with reference to photography, on the other hand, from the modernist style developed by the amateurs of photographic circles reworking the experience gained by the European avant-gardes since the previous decade. All these innovations led to a rethinking of the usual relationship between image and text, gaining a new and a much more dynamic interaction between visual and textual. Through the analysis of some of the most important photobooks of the Fascist Era, the following article aims to show some aspects of the verbal and visual rhetoric which the Fascist regime used to generate an articulated model of the world in which to believe, even if its appearance differed radically from what one saw with one's own eyes or experienced on one's own skin every day. In propaganda photo books, the facts are emphasized, even judged, in order to construct a specious argument that leaves no room for doubt.

\section{Introduction and Literature Review}

The history of Fascist propaganda photography is an emblematic story of how, in the 1920s and 1930s, photography participated in the political events of the Nation, contributing to the construction of an epic and heroic tale of the Italian totalitarianism.

The participation of the photograph was not limited to the figurative investigation of the main appointments of the regime schedule, as well evidenced by the images of the L.U.C.E. Institute, ${ }^{1}$ caged by the compositional conditioning

*Phd, Subject Expert, Faculty of Cultural Heritage, University of Salerno, Italy.

1. The National Institute L.U.C.E. - acronym of Unione Cinematografica Educativa was a public institution aimed at dissemination of films for educational purposes. It was established by Benito Mussolini with the Royal Decree of 5 November 1925. To gain insight into the pecularities and the protagonists of the Institute's Photographic Section see: S. Mannucci, La Fotografia dell'Istituto L.U.C.E. Storia e Critica (s.n., s.l., 2014); G. D'Autilia, L.U.C.E. The Italian Collective Consciousness (Rome: Rai Edu and L.U.C.E. Institution, 2014); D'Autilia, Il Fascismo senza Passione. L'Istituto L.U.C.E, in L'Italia del XX Secolo. Le Fotografie e la Storia, edited by G. De Luna, G. D'Autilia and L. Criscenti, 91116 (Turin: Einaudi, 2005). 
dictated by the ministerial service notes. ${ }^{2}$ Instead, to inspire an enthusiastic adherence to a certain vision of the world, it was necessary to resort to visual narration in which the observer becomes the pivot of an emotional experience, participating in, and sharing, what is perceived through the mechanical eye. Not by chance, in an article published in the international magazine "Galleria", photographer Mario Bellavista defined 'fascist photography' as a type of photography capable of idealizing any image of Italian contemporary life. That is, a type of photography, "that gives the mark of the revolutionary spirit with which the fascism has given a new aspect to the country and to life." 3

To satisfy its apologetic needs, Fascism preferred to use the language of modernist photography, which Italian photographers had developed by studying the European and Soviet avant-gardes. Its verisimilitude, rediscovered and claimed, allowed it to be a witness of a certain historical period; its style, characterized by unusual points of view and a dramatic use of contrasts, made it an instrument that enhanced the natural vision, that is, an instrument capable of capturing aspects of reality. ${ }^{4}$ In this way, photography became an instrument capable of amplifying the physiological abilities of the human eye by capturing aspects of reality that escape natural perception and guaranteeing an aesthetic experience of the world. The essence of modern photography lied in the

2. For an accurated analysis of the system of control, censorship and direction of printed activities see: G. Ottaviani, Le Veline del Minculpop: Aspetti della Propaganda Fascista (Milan: Todariana, 1999); N. Tranfaglia, La Stampa del Regime, 1932-1943. Le Veline del Minculpop per Orientare l'Informazione (Milan: Bompiani, 2005). Furthermore, a telegram of July 31 1925, sent by the Minister of the Interior Luigi Federzoni to the prefects, was found at the Central State Archives of Rome. The telegram laid down a series of rules to avoid the reproduction in print of photographs concerning murders, thieves, adulterers, in order to prevent the risk of diverting public opinion (see ACS, MCP, Gabinetto, Black Chronicle, b. 3, f. 11, telegram n. 17916). In the Morgagni Documents, then, appears a directive in which it was required to publish only the images of the Duce that revealed his personality in a dignified way (ACS, Agenzia Stefani, Morgagni Documents, b. 3, f. 7, orders of March 18 and April 30,1932). Another service order forbade to publish photographs of soldiers who left their homes saying goodbye to their families (cf. ACS, MCP, b. 185, f. 34, order of 27 July 1935): they were always to be shown in imposing masses, in which the Italian "race", with its pride, boldness and youthful strength, was to be clearly visible (cf. ACS, MCP, b. 75, report of 3 September 1939).

3. M. Bellavista, "Per un'Arte Fotografica al Tempo di Mussolini," Galleria 14, no. 4 (1936): 5.

4. To gain insight into the history of Italian modernist photography see: S. Paoli, "L'Annuario di Domus del 1943" in Fotografo e Collezionista (Dedicated to Paolo Costantini, Photographer and Collector), edited by T. Serena and A. Paolo Costantini, 99128 (Pisa: Scuola Normale Superiore, Pisa, 1999). 
possibility of telling the world, of making it easier to understand. ${ }^{5}$ Not by chance, in his Discourse on photographic art of the 1932, Gio' Ponti said:

Photography ha revealed to us a new aspect of things, it has brought us to a whole new understanding, a whole new sense of them [...] Photographic aberration is our only reality, even our knowledge and our judgment [...], it is a great part of our visual learning. ${ }^{6}$

Conceiving photography as an art that finds its raison d'être when its language becomes functional to communication, made it vunerable to the needs of the regime, which used it to influence common opinion through the financing and the production of propaganda photobooks.

In analyzing these fascinating products of semiotic engineering, one comes up against the ambiguity of the term: according to the critic David Campany, the English expression 'photobooks', commonly used by those who study photographic books, is not an innocent term, because it was created and used to impose coherence in a field where there is none. ${ }^{7}$

In Italy, the bibliography on the subject is still to be written. An early systematization was attempted by Antonella Russo: in her Il Fascismo in mostra she tried to analyze the structural aspects of Fascist propaganda photobooks, without being able to trace its origins and the reasons for its birth. ${ }^{8}$ Four years later, in the magazine "AFT. Rivista di Storia e Fotografia", Giorgio Chiti signed a catalogue of the Italian photographic books published between 1940 and 1980, ${ }^{9}$

5. In this regard, in an article which comments on the International Exhibition of Photography at the V Triennale di Milano, the graphic and photographer Antonio Boggeri said: "But another absolutely new element, capable of inebriating our virgin sensibility, is conquered by the marvelous images that do not belong to the common and natural domain of our eyes. Outside the limited possibilities of our visual means, we hide images that the photograph takes and reveals" (A. Boggeri, "La Fotografia alla Fiera di Milano," Natura 5, no. 3 (1932): 45).

6. G. Ponti, Discorso sull'Arte Fotografica," Domus 5, no. 53 (1932): 285-286.

7. "[...] I rather miss those days before the dubious term 'photobook' became so widespread. It's not an innocent word. It has been welcomed and taken up in order to impose some kind of unity where there simply was none and perhaps should be none. A few years ado I wrote this in the British magazine Source: "The compound noun 'photobook' is a nifty little invention, designed to turn an infinite field (books with photographs in them) into something much more definable. What chancer would dare try to coin the term 'wordbook' to make something coherent of all books with words in them? But here we are. A field needs a name and until we find a better one we're stuck with 'photobook'" (D. Campany, "The Photobook: What's in a name? The Photobook Rewiew," Aperture 7 (2014): 3).

8. Cf. A. Russo, Fascismo in Mostra (Rome: Editori Riuniti, 1999), 30-31, 163-184.

9. See G. Chiti, "Il Libro Fotografico in Italia dal 1940 al 1980," AFT. Rivista di Storia e Fotografia 19, no. 37/38 (2003): 78-111. 
but it was only in 2016 that a broader study, embracing ages and geographies of the book even very far apart, was published by Cecilia Piazza. The author tried to cross the uncertain terrain in which the artist's book meets design and production through the use of photography. Although she investigated all the possible variations, the photobook does not seem to be subject to a perfect focus. ${ }^{10}$

However, if we try to leaf through some magazines from the 1930s, we can read articles that offer a more precise description of a photobook and allow us to establish an internal chronology of the genre, marking its evolution. In the early Thirties, the photographic book - or photobook - was considered "an authentic photographic encyclopedia in miniature."11 An early example is undoubtedly L'Italia Fascista in cammino, published in 1932 by the National Institute L.U.C.E. on the occasion of the tenth anniversary of the March on Rome, as a figurative compendium of the activities carried out by the regime. In the preface, Duce himself reveals the pourpose of the pubblication, that is "to pay homage to the Truth and Action as a guide for human beigs provided with good effort."12 With his words, he conditioned the interpretation of the images that flow in the following pages. Here photography is a reliable documentation and bears witness to the reliability of the opening statements. It plays a subsidiary role, simply illustrating the event or theme narrated. ${ }^{13}$

Instead, in the middle of the decade, an anonymous voice of the editorial staff of "Natura" took note of a change of direction, declaring that "after the examples coming from abroad, in Italy too volumes of a certain importance are published, in which photography is the protagonist for itself." 14

In fact, in the volumes after 1935, the conflict/collaboration between image and word is resolved in favour of photographic reproduction, which, even though it is described by a written text, becomes the protagonist of the layout. Its function is to provide a vision-representation of reality improved by the interventions of the regime, immediately succeeding in captivating the reader that the written text would have struggled to conquer.

10. Cf. C. Piazza, Pho-to-Booked. Un Libro con le Foto di 107 Libri con le Foto (Rimini: Digitalprint, 2016), 516.

11. Rich, "Finalmente un Libro," Il Corriere Fotografico 36, no. 4 (1939): 98. By the same author see also: Rich, "Bibliografia Fotografica," Il Corriere Fotografico 36, no. 2 (1939): 4143 , while on the same subject it is worth mentioning Anonymous, "Il Volto della Nuova Italia,"Il Corriere Fotografico 30, no. 6 (1933): 31.

12. B. Mussolini in L.U.C.E., L'Italia Fascista in Cammino (Rome: Istituto Poligrafico dello Stato, 1932).

13. Also Alfredo Panzini, in the introduction to Axel von Graefe's photographic book, insists on the testimonial value of photography and the need for it to be combined with words that explain its meaning: "The precise and scientific language of the photography needs the kit of the words" (A. Panzini in A. Von Graefe, Il nuovo volto d'Italia (Milan: Mondadori, 1933), s.p..

14. Anonymous, “Libri Fotografici,”Natura 8, no. 10 (1936): 27. 
Thus, the photographic book, or photobook, becomes "a book [...] in which the main message is conveyed by photographs."15 It tells a different kind of truth from that given by the single frame, a truth that becomes available only in the interstices between the images, connecting art to the mass medium.

A photobook is an autonomous art form, comparable with a piece of sculpture, a play or a film. The photographs lose their own photographic character as things 'in themselves' and become parts, translated into printing ink, of a dramatic event called a book. ${ }^{16}$

\section{La Sua Terra (1936)}

The definition of photobook offered by Martin Parr is surprisingly close to what the photographer and animator of the Italian modern photographic movement Guido Pellegrini wrote in 1936. From the pages of the monthly magazine "Galleria" he describes the "book of today" as "a living cultural entity", addressed to be "a sort of film, which is read rather than performed."17 This kind of definition tries to force the banks of narrative models centred on the domain of the text and which suddently became inadequate to meet the needs of a publishing industry in tune with the spirit of the times. In order to narrate the new and seduce the contemporary audience, the book had to entrust its hermeneutical significance to photography. Consistently with the culture of the gaze theorized since the beginning of the decade, photography mixed the domain of art in search of new expressions of reality, and showed itself more relevant to everyday life.

Going on with his reflections, the author traced an interpretation, "the most genuine," of modern book, characterized by:

[...] a choice iconographic documentation, which accompanies and materializes the most dynamic situations. This documentation, integrated by the graphic characters, perfect in form and style, clear intelligible, must support the periods, enliven the movements described, harmonize comparisons. The modern book reveals fine aesthetic sensations with throbbing, vivid, new and unpredictable images; we will not see the photographs on separate pages, but interposed and joined to the story, so as to 'read' them without taking our eyes off the text. A sentence interrupted by an image forces the reader to see and follow the reading, the 'thread' of meaning, while the thought actively unfolds; the writer is truly supported by the illustration, which gives the book the help of its infinite resources. ${ }^{18}$

15. M. Parr and G. Badger, The Photobook: A History. Volume I (London: Phaidon, 2004), 6 .

16. R. Prins, quoted in Ivi, 7.

17. G. Pellegrini, “La Fotografia e il Libro Moderno,” Galleria 15, no. 1 (1936): 3.

18. Ibid. 
A first example that seems to respond to indications of Guido Pellegrini was published in 1936: it is La mia terra (His Land), a photobook created as a supplement to the monthly magazine "Il Rubicone", edited by Giuseppe Massani, director of the magazine and author of all the photographs that appear in it. The account narrated by what its author defines as a "peasant book"19 correlates the events linked to Mussolini's youth with those of the people who live in the countyside around Predappio, translating the praise of a community into a commendation of the Duce. But the moral, physical, existential distance between the two parts of the story is restored by photographs. The images of Predappio's community are images of faces, of men and women intent on working or gathered together on a public holiday: in short, images that document the life and habits of a small town (Figure 1).

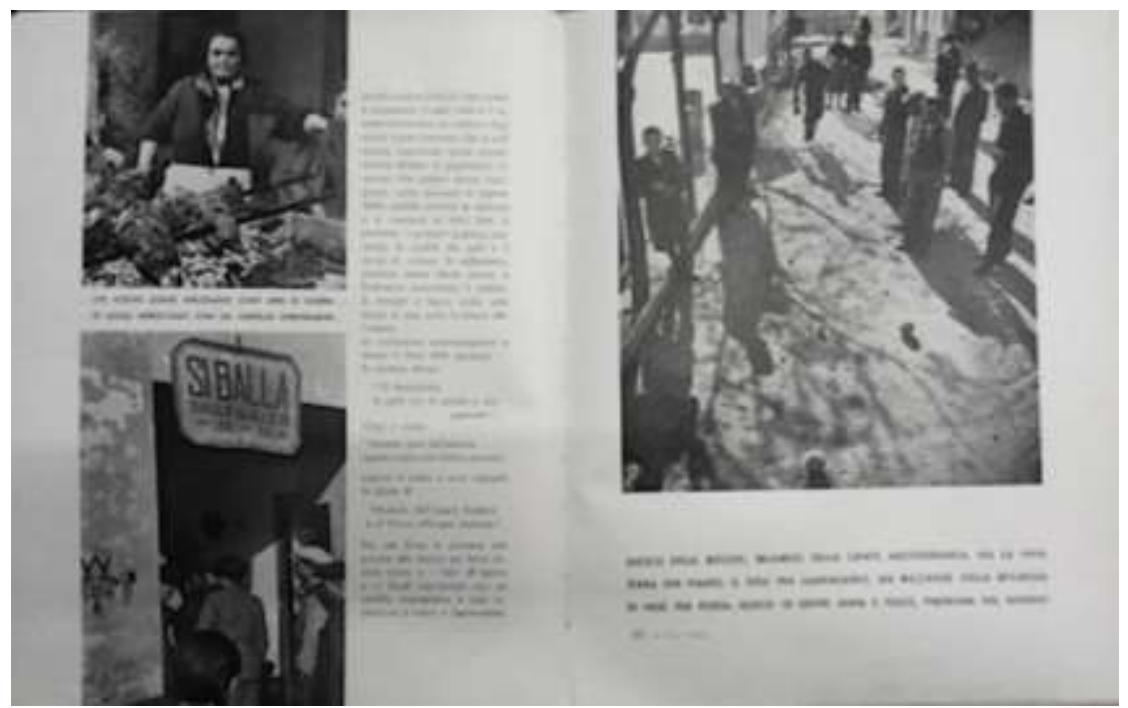

Figure 1. Images of Predappio's Community from the Photobook La Sua Terra, ed. Giuseppe Massani, Istituto d'Arti Grafiche, Bergamo, 1936, pp. 36-37, Private Collection

The Duce's photographs, instead, are not portraits taken from the family album nor hyperbolic official cerimonial poses; rather, they are details of places (the banks of the river Raggi, the Gaiani's house) and objects (beds, blanket, bread, rifle) in which Mussolini hovers like a presence without ever showing himself. This sort of secular figurative consubstantiation contributes to the idealization of the Head of State, creating a psychologically emotional image, capable of impressing the viewer by inducing him to sympathize and mythologize the fascist dictator (see Figures 2 and 3).

19. G. Massani, La Sua Terra (Bergamo: Istituto Italiano d'Arti Grafiche, 1936), 7. 

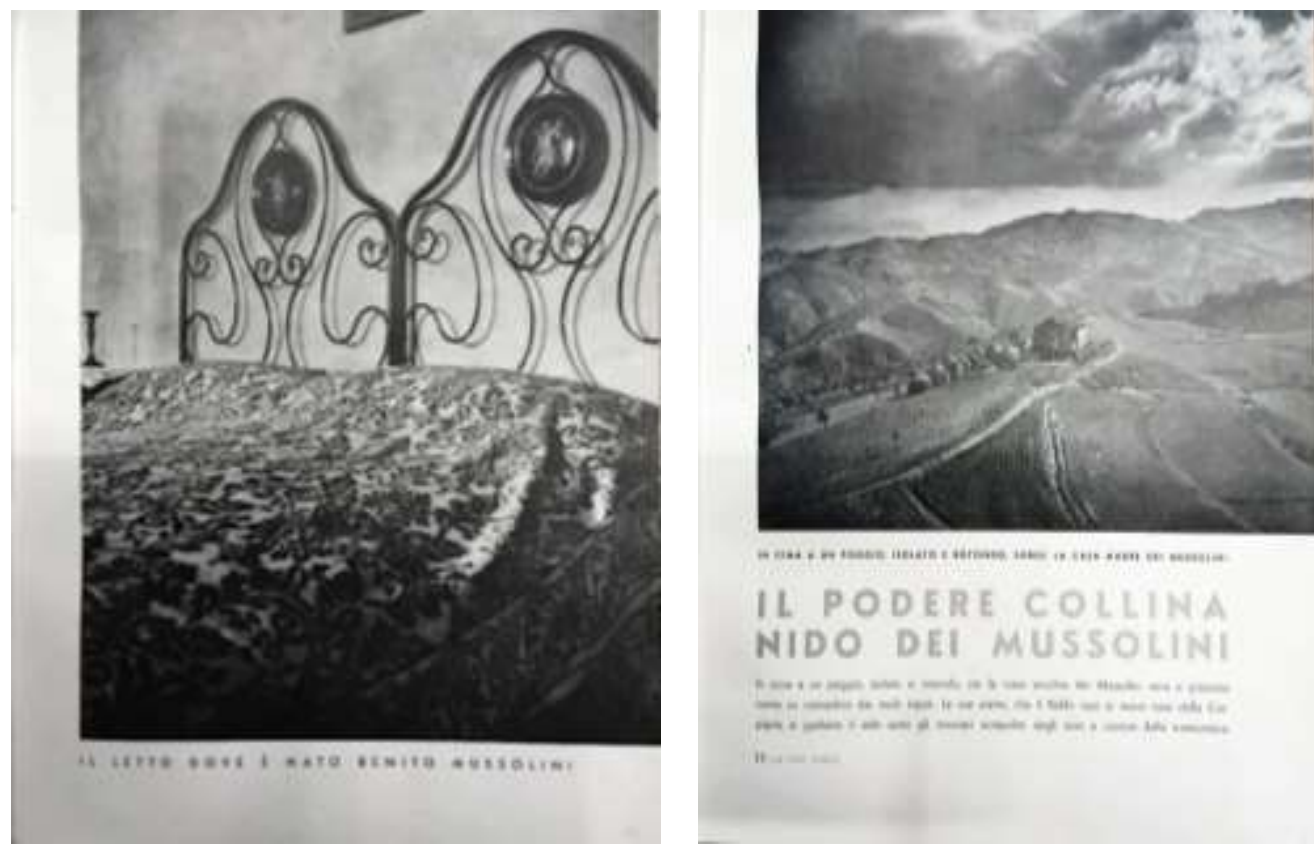

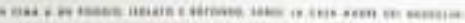

IL. PODERE COLLINA

NIDO DEI MUSSOLINI

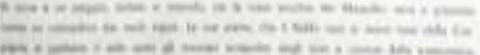

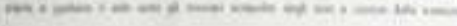

Figures 2 and 3. The Bed where Mussolini Born (on the left) and The Mussolini's Farm (on the right) from the Photobook La Sua Terra, ed. Giuseppe Massani, Istituto d'Arti Grafiche, Bergamo, 1936, p. 9 e p. 11, Private Collection

Another feature that qualifies La sua terra as a modern book is its rendering. As a matter of fact, the possibility of a Fascist Head of State's Mythopoeia had also been supported by the renewal in the typographical environments. It was the critic and printer Guido Modiano who started the debate on the subject. He had travelled around Europe in the Twenties and had become aware of all the experiments of the avant-garde in the field of graphics. ${ }^{20}$ Thus, already in an article of 1931 he had shown that the massive introduction of photography into the mass media had necessarily led to a rethinking of the assumptions on which typographic knowledge was based:

Not only with the contribution of 'illustration' current photography can help us printers. It raises new aesthetics, new decorative means, it proposes clever and tasty solutions to certain problems of decoration. In a typography aware of the new times, decorative motifs must be reduced to a minimum and move away, in what little remains of them, from abused patterns. The photographic taste induces us to replace

20. To gain insight into the history of the graphic design see: P. B. Meggs, A History of Graphic Design (New York: J. Wiley \& Sons, 1998); B. Gomez Palacio and A. Vit, Graphic Design Referenced: A Visual Guide to the Language, Applications and History of Graphic Design (Beverly: Rockport, 2010); J. Müller and J. Wiedemann, Graphic Design: 1890-1959. Volume 1 (Köhln: Taschen, 2019). On the Italian case, cf.: F. Colombo, Libri Giornali e Riviste a Milano: Storia delle Innovazioni nell'Editoria Milanese dall'Ottocento ad Oggi (Milan: Abitare Segesta, 1998); A. Chinellato and C. G. Noventa, La Superficie Bianca. Il Prodotto Editoriale tra Storie e Progetti (Padova: Libreria Universitaria, Padova, 2013). 
the worked frames and the fillers of each style with the superimpositions of screens and texts, which [...] arouse a technical atmosphere. ${ }^{21}$

The two elements of the Italian printer's discourse are therefore connected: in order to better serve its purposes, such as the clarity and the strenght of the message, the typography must enhance and support the structures of the imagine; on the other hand, photography can help graphics to leave old patterns.

Guido Modiano's reflections anticipate the themes of "Campo Grafico" [1933-1939], an Italian magazine of aesthetics and graphic tecnique that aimed to present, among its pages, the whole range of modern typography. ${ }^{22}$ It banned the rigidity of the models inherited from the past and proposed ingenious graphic solutions, which acted as demonstrators of particular design and execution methods. It is no coincidence that in the editorial of the first issue of the magazine, the director wrote:

A technical-demonstrative magazine missing from the graphics field. Through the publication of many practical examples made with clear aesthetic concepts, we support the ideas of the current graphic art and divulge the continuous changes in trends and means in this era of fruitful progression. "Campo Grafico" will be different from other magazines because of its original conception: it will keep a limited number of pages in order to allow a complete change of layout and cover for each issue. The advertising itself will be renewed each time. ${ }^{23}$

So, the typographic revolution had been supported by a heavy penetration of a dynamic and expressive element such as photography into printed production; at the same time, however, the study of the layout became essential in order to support the intentions of the message, promoting a new and stronger connection between image and text.

Going back to La sua terra, in order to improve the relationship between the photographs and the written text, the layout combines the images so as to establish an agreement or, conversely, a contrast between the characteristics of each shot. Words, instead, don't only provide information useful to understand

21. G. Modiano, “Fotografia," L'Industria della Stampa 3, no. 6 (1931): 102. The article has been entirely republished in "Campo Grafico" 2, no. 12 (1934): 274-275. To gain insight into the Guido Modiano's activities, see: M. Chiabrando, "Guido Modiano e la Nuova Tipografia Italiana," in TDM5: Grafica Italiana, edited by G. Camuffo, M. Piazza and C. Vinti (Mantova: Corraini; Milan: Triennale Design Museum, 2012), 60; C. Vinti, “Modiano e la 'Mostra Grafica' alla VII Triennale," Progetto Grafico 4-5 (2006): 50-63.

22. To gain insight into the history of the magazine, see: AA.VV, Campo Grafico: La Sfida della Modernità (Milan: Centro Studi Grafici di Milano, 2003); G. Pellittieri and O. Rossi, “Campo Grafico," Homo Faber 20 (1953): 1-8; C. Dradi, Millenovecentotrentatre: Nasce a Milano la Grafica Moderna (Milan: Ufficio Stampa del Comune di Milano, 1973); AA.VV, Campo Grafico: 1933-1939 (Milan: Electa, 1983).

23. A. Rossi, "Scopi Semplici,” Campo Grafico 1, no. 1 (1933): 3. 
the meaning of the visual part: quoting pieces of a Benito Mussolini's book, ${ }^{24}$ they further increase the narrative structure. Moreover, they begin to impose themselves as an image tout court, changing the width and type of character and setting a visual continuity between the pages (see Figure 4).

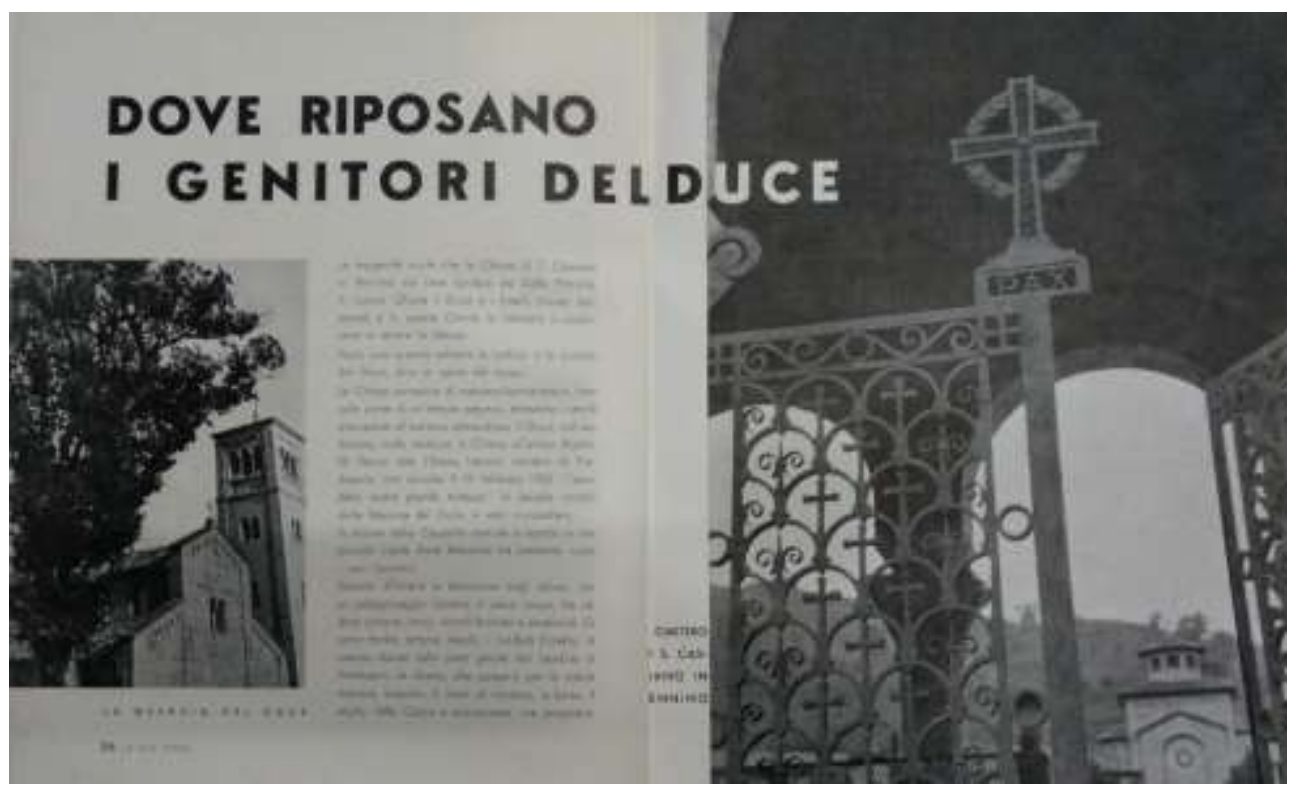

Figure 4. Where the Duce's Parents Rest from the Photobook La Sua Terra, ed. Giuseppe Massani, Istituto d'Arti Grafiche, Bergamo, 1936, pp. 56-57, Private Collection

\section{Italia Imperiale (1937)}

Italia Imperiale (Imperial Italy), the most monumental of the propaganda photobook wanted by Fascism, was announced by a long-lasting advertising campaign in 1936 and was published the following year as supplement to the monthly magazine "La Rivista Illustrata del Popolo d'Italia." 25 The photobook tells the story of Italian ventures in East Africa until the foundation of the Fascist Empire (9 May 1936). His contemporaries considered it "the documentary corpus of political, propagandistic, military, industrial and commercial activities imposed by a single will," ${ }^{26}$ organized in order to "make the reader feel all the moments experienced by Mussolini's Italy, make him understand the greatness of certain actions, the importance of the sacrifices made and the results achieved." 27 To realize this ambitious editorial project, it had been necessary to use "a layout that,

24. The reference is to the Arnaldo Mussolini's biography, written by Benito Mussolini in 1932 to commemorate his brother's death. Cf.: Mussolini, Vita di Arnaldo, 1932.

25. The volume is $44,6 \mathrm{~cm}$ long and $37.5 \mathrm{~cm}$ wide, for a total of 624 pages.

26. Anonymous, “Italia Imperiale," L'Ufficio Moderno 13, no. 7 (1937): 341.

27. Ibid, 342. 
by the power of agreements and contrasts, would renovate the enthusiasm of the moments experienced." 28

In Italia Imperiale photographs occupy entire sequences of pages; observing them, one notices the repetition of a characteristic way of shooting that tends to bring the lens very close to the framed object, returning only details of it. This is a device that helps to create icons, to device visual symbols, which more than documenting a fact, contribute to its mythification (Figures 5 and 6).
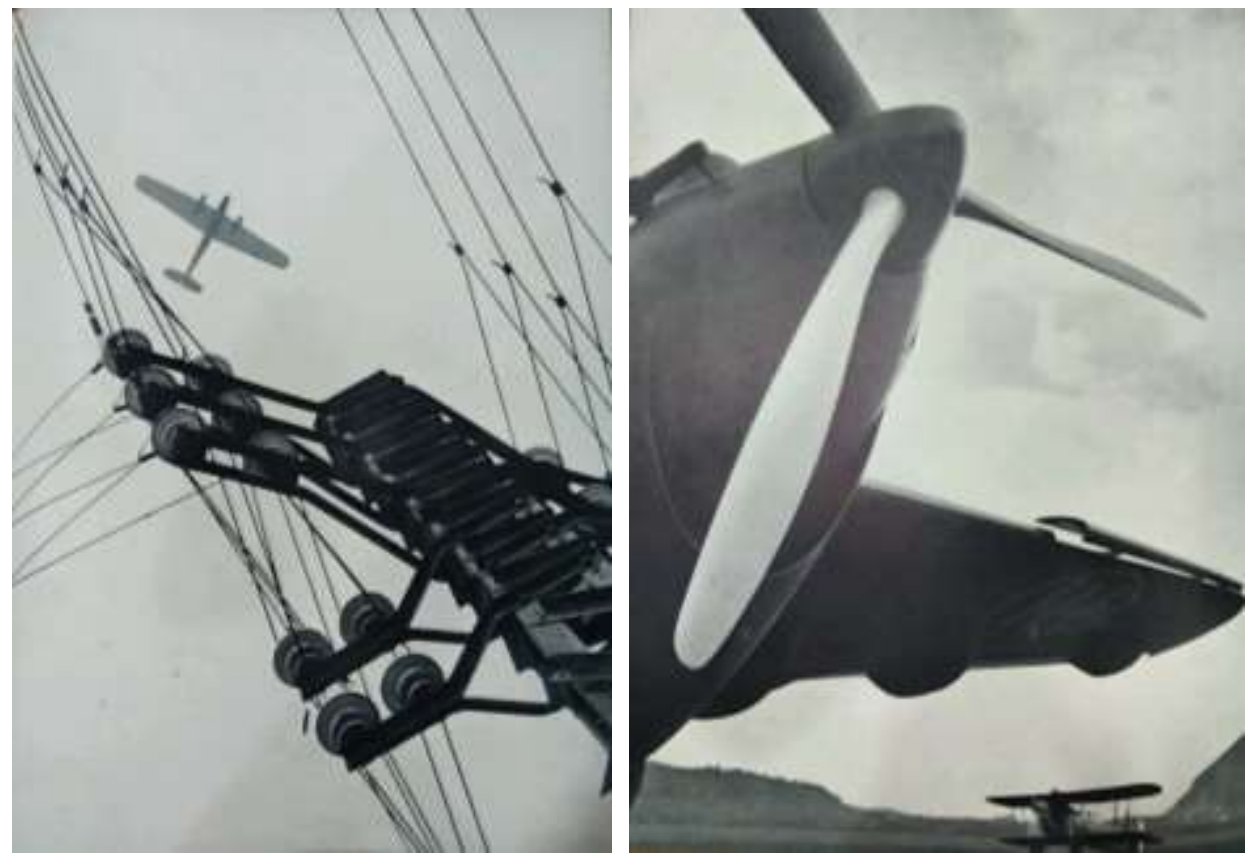

Figures 5 and 6. Some Photographs from the Photobook Italia Imperiale, Curated by Manlio Morgagni and Luigi Poli, Stabilimento Arti Grafiche, Alfieri\&Lacroix, 1937, Private Collection

In the section of the photobook that pays homage to the companies that had supported the African feats by converting all or part of their production, there is a more mature layout than the previous example.

The line spacing and the font size is modified with each topic change. Shortleg characters used when there is a need to contain as much text as possible within the page; on the other hand, elongated characters allow to create a brighter layouts, on which the eye can rest.

When two pages of text follow one another, one tries to break the monotony of the writing leaving wider edges on top and on the bottom of the page. This is a type of layout that betrays the tendency to organize the narrative matter considering the two parts of the sheet as a single one.

28. Ibid. 


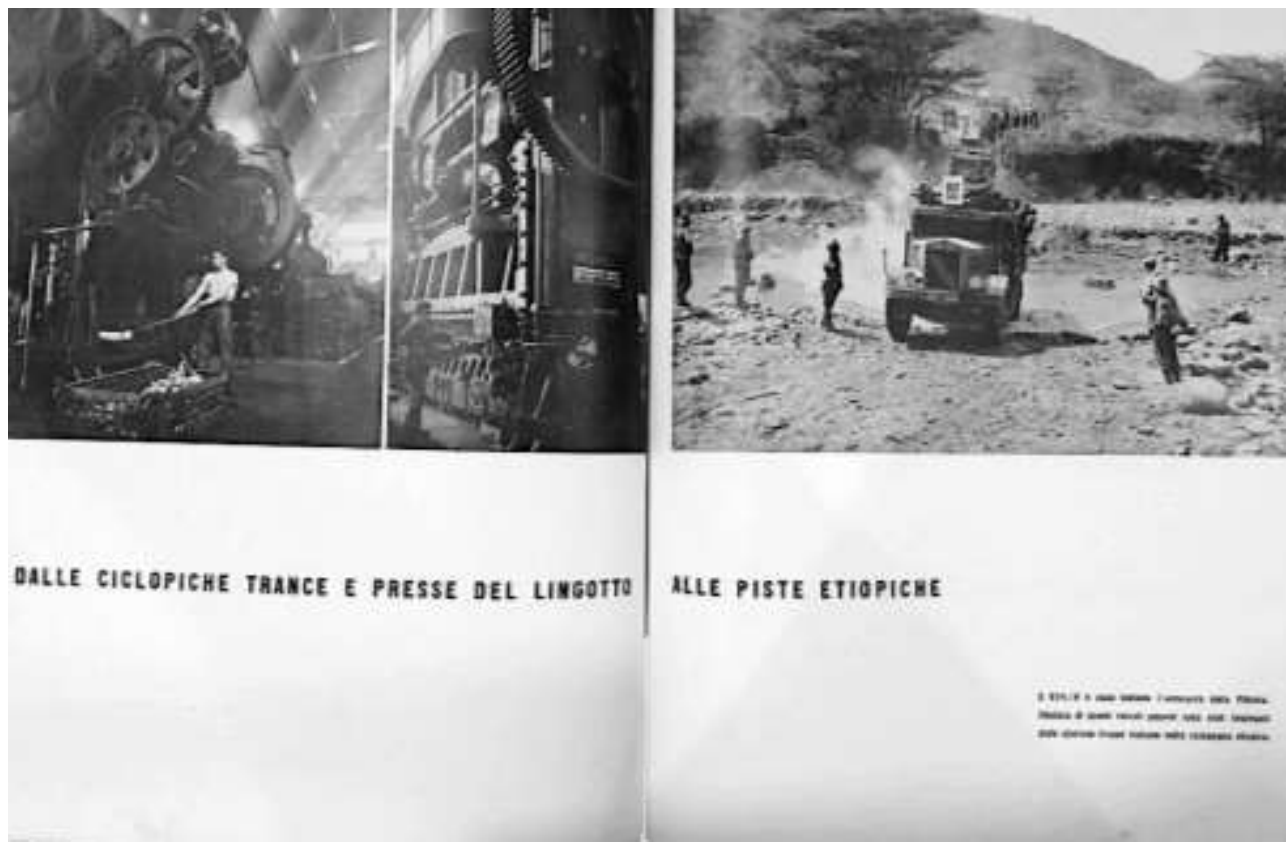

Figure 7. The Mechanical Industry of the Fascist Italy from the Photobook Italia Imperiale, Curated by Manlio Morgagni and Luigi Poli, Stabilimento Arti Grafiche, Alfieri\&Lacroix, 1937, Private Collection

The proposed image can help us to better understand how the graphic choices allow new and more sophisticated interactions between the photographs and the written text. The latter is reduced to a string of letters that crosses the left page to continue on the next one; thanks to the use of bold, the characters acquire a plastic effect and stand out against the surrounding white. Captions and photos are organized according to a mirror structure, where each image - and its tagline - is retired to a page. Nonetheless, they must be read as a whole, because each shot refer to the structure of the other one by contrast or symmetry. In this way, the sequence of terms becomes the geometric center around which the other elements of the graphic composition are arranged. The string clarifies and reveals the game of affinities: with its movement it forces the reader's eye to move on a wider surface while its semantic value strengthens the analogies between the photos, even when they appear far apart (see Figure 7).

Another feature of Italia Imperiale is the presence of photomontages, which often combine documentary intentions and aesthetic qualities, giving a strong added value to the propaganda message. The example proposed here is an assembly work made by Erberto Carboni..$^{29} \mathrm{He}$ realized a hand-drawn diagram of all the forces that made up the Fascist Party, using photographic cutouts (Figure 8).

29. The attribution of the photomontage at issue to the italian architect, designer and advertiser is in: N. Baltzer, Die Fotomontage im Faschistischen Italien. Aspekte der Propaganda unter Mussolini (Berlin: de Gruyter, 2015), 191. 
The transformation of the individual into a symbols had already begun in 1922 with the adoption of the Roman salute by Mussolini's supporters, "greeting of the Latin race, greeting of the legionnaries, with a powerful history and a heroic tradition." 30
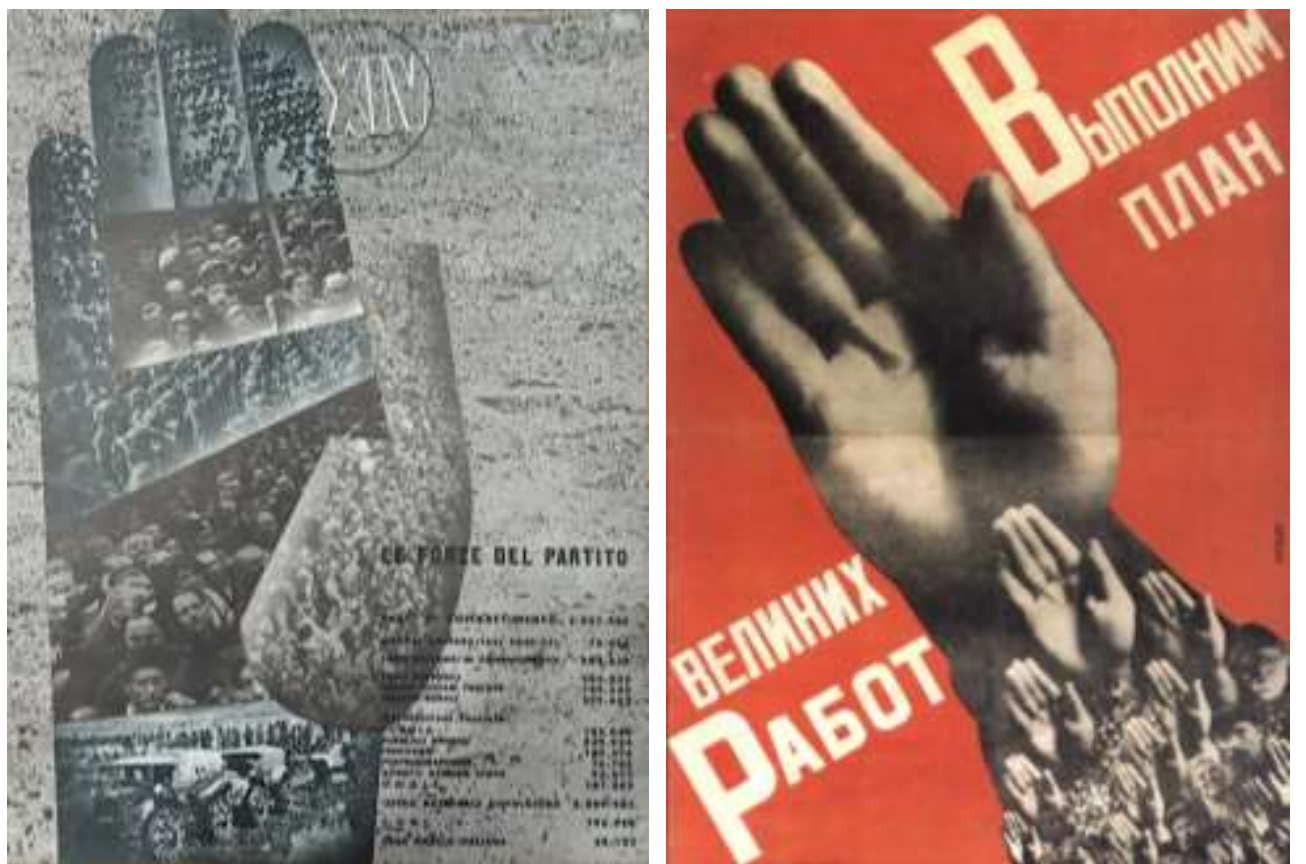

Figure 8. (on the left) Erberto Carboni, Party Forces, Photomontage from the Photobook Italia Imperiale, Curated by Manlio Morgagni and Luigi Poli, Stabilimento Arti Grafiche, Alfieri $\mathcal{E}$ Lacroix, 1937, Private Collection

Figure 9. (on the right) Gustav Klutsis, Manifesto Celebrating 13 th Anniversary of the October Revolution, Photomontage from the Photobook Italia Imperiale, Curated by Manlio Morgagni and Luigi Poli, Stabilimento Arti Grafiche, Alfieri\&Lacroix, 1937, Private Collection

However, the iconic motif of the extended hand is not exclusively linked to the fascist ideology: in 1930 Gustav Klutsis used it to make the manifesto celebrating the thirteenth Anniversary of the October Revolution. Also here a large palm stands out against the orange background while small copies of the same images and small heads are juxtapose along the wrist (Figure 9).

In both examples, the photographic icon is documentation and monumentalisation of a thought at the same time; in both examples the large hand shows the way. It is the idea, the symbolic representation of the people as a decision-making apparatus, acting as a unity.

Even the photomontage that closes the chapters dedicated to the corporate system serves to make a theme intelligible by playing on the prevalence of the visual signifier over the verbal one. The system of production planed by the regime acquires mechanomorphic features and opens up its deep metal belly to

30. Starace “Editorial," 1933, 1. 
reveal its functioning: there are tubes that look like oesophagi, valves, cylinders and ladders on which the anonymous mass of the workers rises. At the centre of the image there are two graphically designed cogwheels, which synthesize and corroborate the representation of a well-run economic system through the perfect joint of his gears (Figure 10).

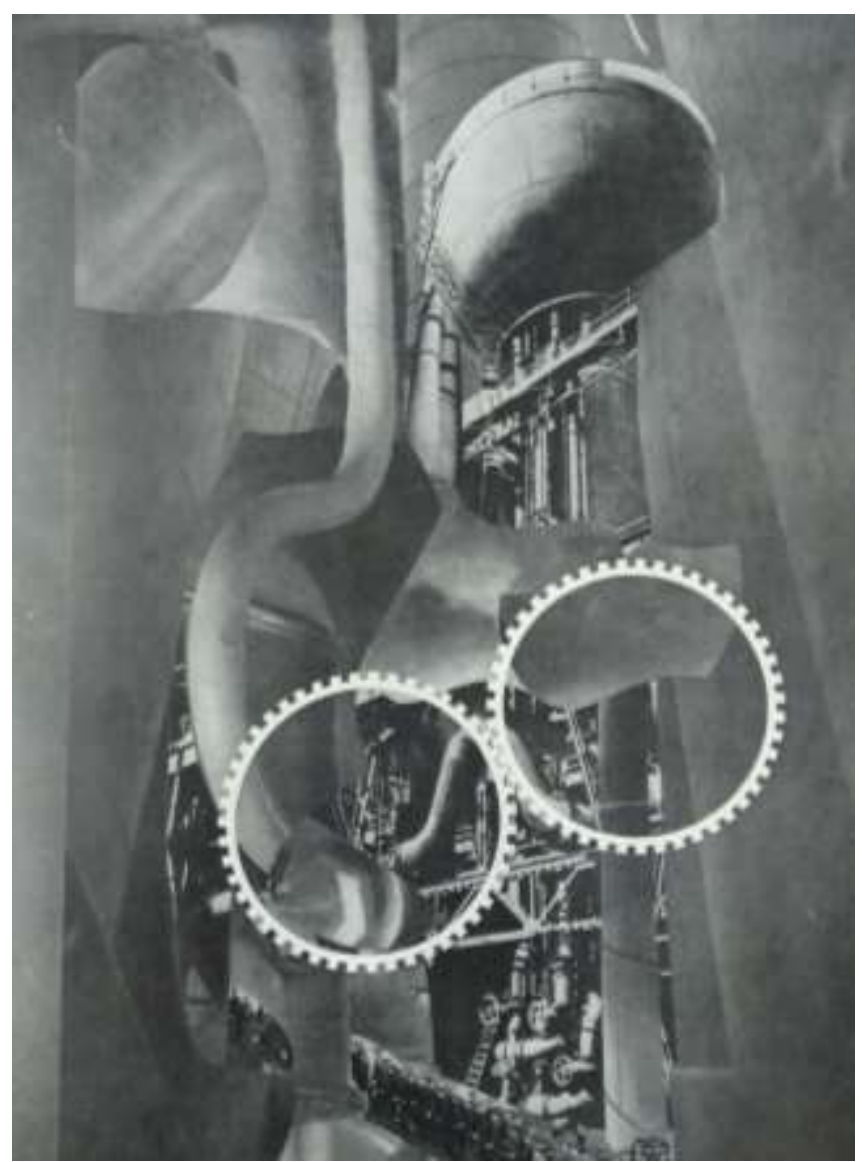

Figure 10. The Corporate System, Photomontage from the Photobook Italia Imperiale, Curated by Manlio Morgagni and Luigi Poli, Stabilimento Arti Grafiche, Alfieri\&Lacroix, 1937, Private Collection

The characteristic of the photomontages in the last pages of the book is a movement induced by curved or diagonal lines: the illusionistic space of the perspective is replaced by the chaotic accumulation of photographic elements, shot from different distances and with different light, to generate a symbolic perspective able of putting together in a page events that take place in spaces and times far apart, as well as in medieval predellas, where each compartment summarized several moments of an action or several moments of the life of a Saint (Figure 11). The suggestiveness of these "manipulation of the reality" 31

31. G. Patti, L. Sacconi and G. Ziliani, Fotomontaggio: Storia, Tecnica, Estetica (Milan: Mazzotta, 1979), 133. 
persuades the observer to firmly believe in the propagated message and amounts to the beginning of a world that would guarantee collective happiness and the population's wealth.

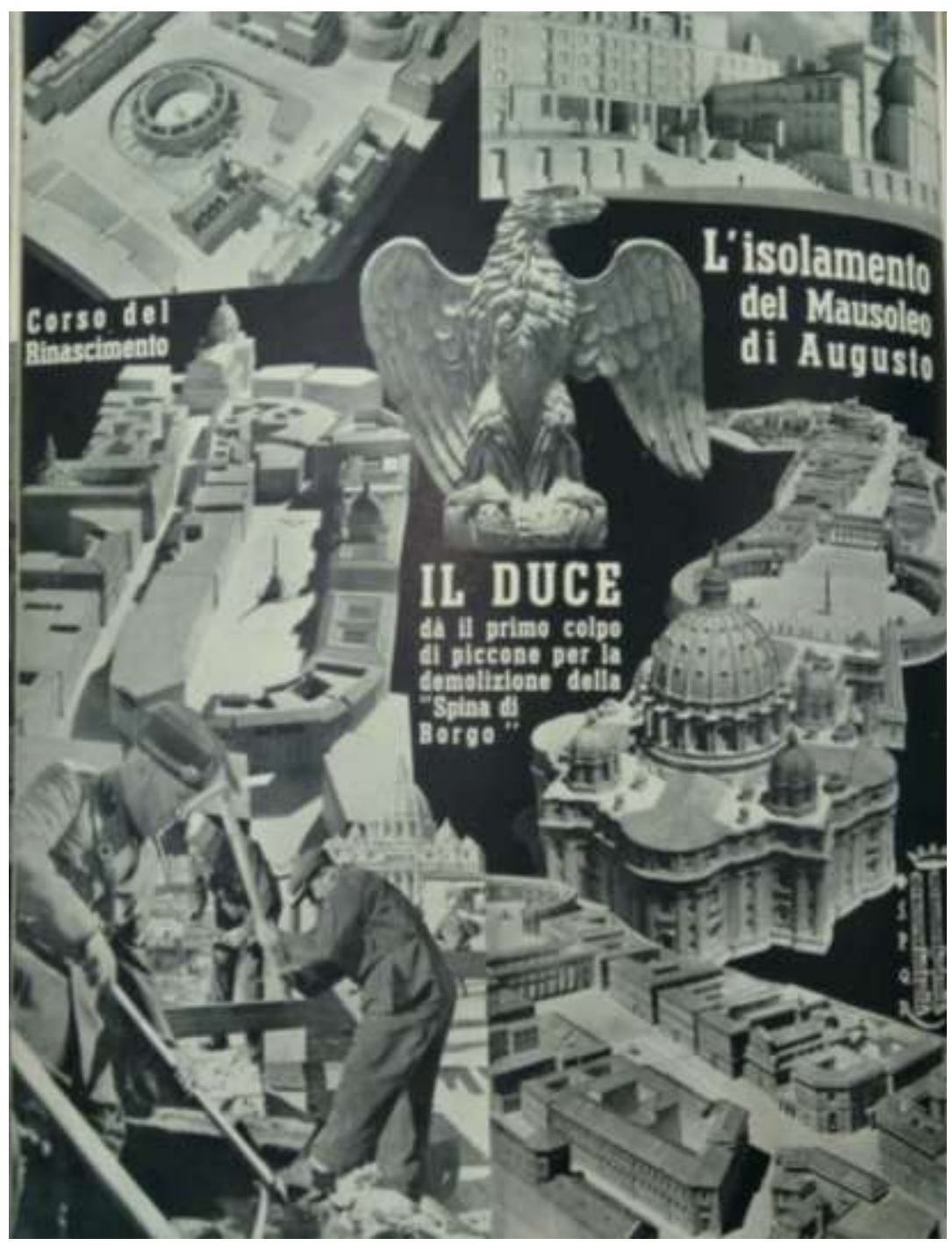

Figure 11. Regime's Construction Project from the Photobook Italia Imperiale, Curated by Manlio Morgagni and Luigi Poli, Stabilimento Arti Grafiche, Alfieri\&Lacroix, 1937, Private Collection

\section{Il Fascio Primogenito (1938)}

The complex interaction between layout, image, word and gaze evolves towards forms characterized by a drastic reduction of writing in favor of an iconic narrative trend in the last photobook suggested: Il fascio primogenito (The first Fascist Lictorian). Published on the occasion of the squadrista's muster in 1939, the volume retraces "the documentation of the most important events that, in every 
sector, had characterized the activity of Milanese Fascism from June 1933 to October 1937." 32

Since in this photo book the text is reduced to a simple introduction, the history of the Party's activities in Milan unfolds through a complex orchestration of visual and figurative elements. Especially the graphic part is well-finished: there are two pages conceived as one and some of them are made up of coloured and transparent plastics, which help to break up the black and white monotony. Often fold-outs are used while the second colour is no longer a pleonastic decoration but a device to accentuate layout values (Figure 12).

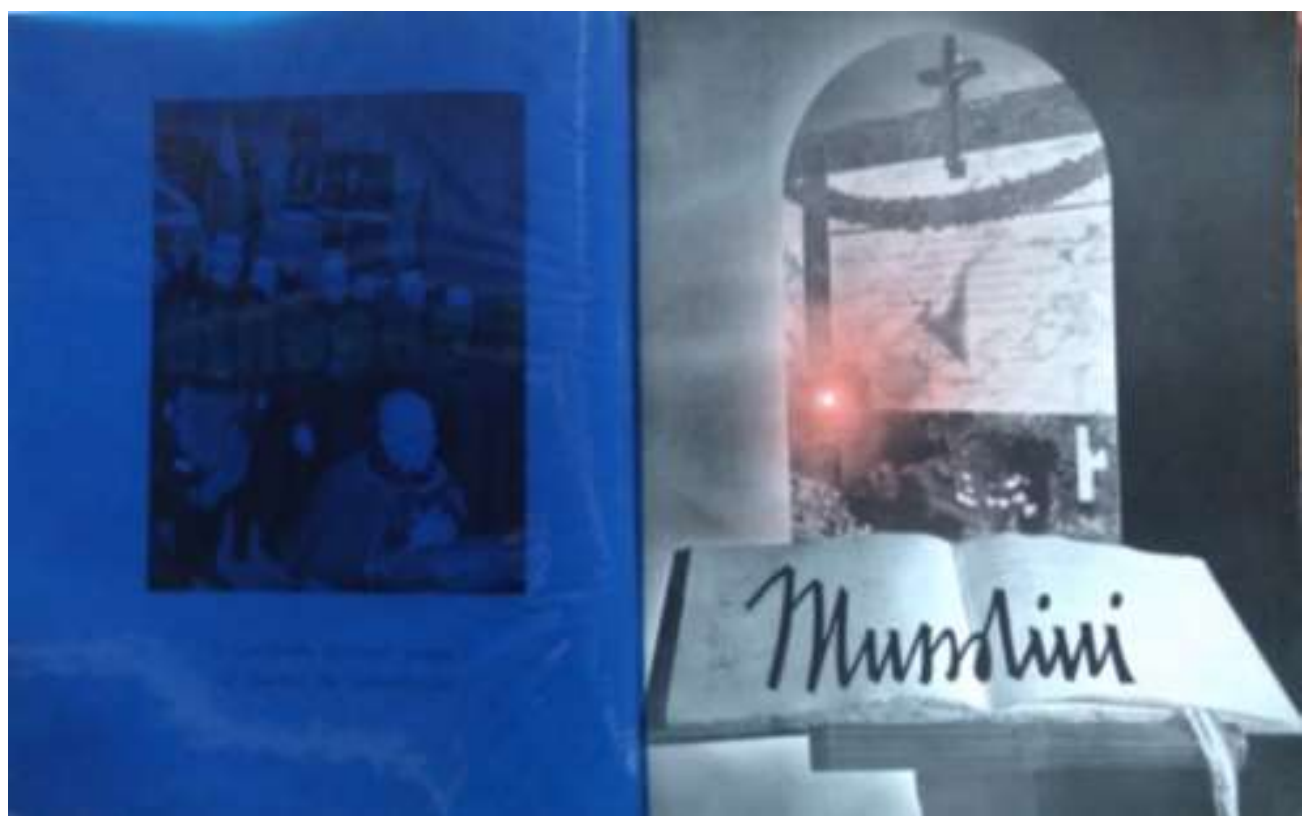

Figure 12. Example of Layout from the Photobook Il Fascio Primogenito, Curated by the Milanese Fascist Party, Officine Grafiche Esperia, Milano, 1938, Private Collection

Also for Il fascio primogenito it can be helpful to scroll and analyze some pages to better understand the visual devices used. One can often come across images where Mussolini appears in the crowd. These are photographs achieved by superimposing cutouts of the Duce to those of the great mass of the people, taking care never to confuse the figure of the Head of State with that of his acolytes. This iconographic choice is based on a certain intention: it abolishs equality in favor of a gap between the Duce and the crowd, "the collective ego in which the individual increases and melts," 33 demonstrating to the reader the superiority of the Head of State. In this way, dictatorial power instilled the idea

32. Cf. Milanese Fascist Party (curated by), Il Fascio Primogenito (Milan: Officine Grafiche Esperia, 1938), III.

33. M. Isnenghi, "Iconografia della Stampa Fascista," Belfagor: Rassegna di Varia Umanità 32, no. 3 (1977): 346. 
that the disparity between human beings was not only essential but just (Figures 13 and 14).

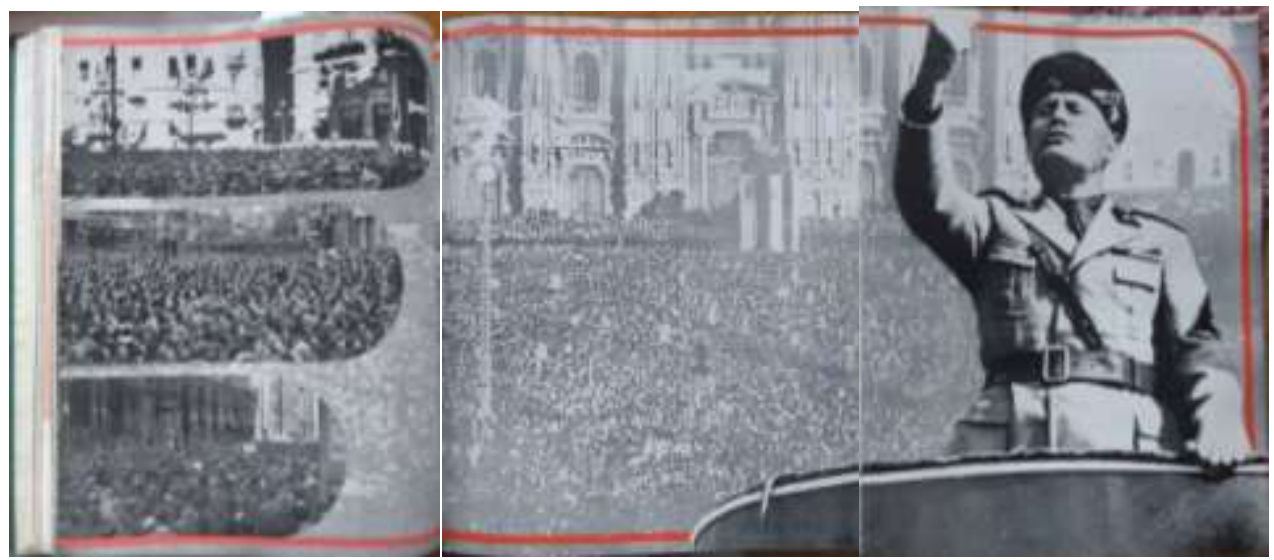

Figure 13. Foldout from the Photobook Il Fascio Primogenito, Curated by the Milanese Fascist Party, Officine Grafiche Esperia, Milano, 1938, Private Collection

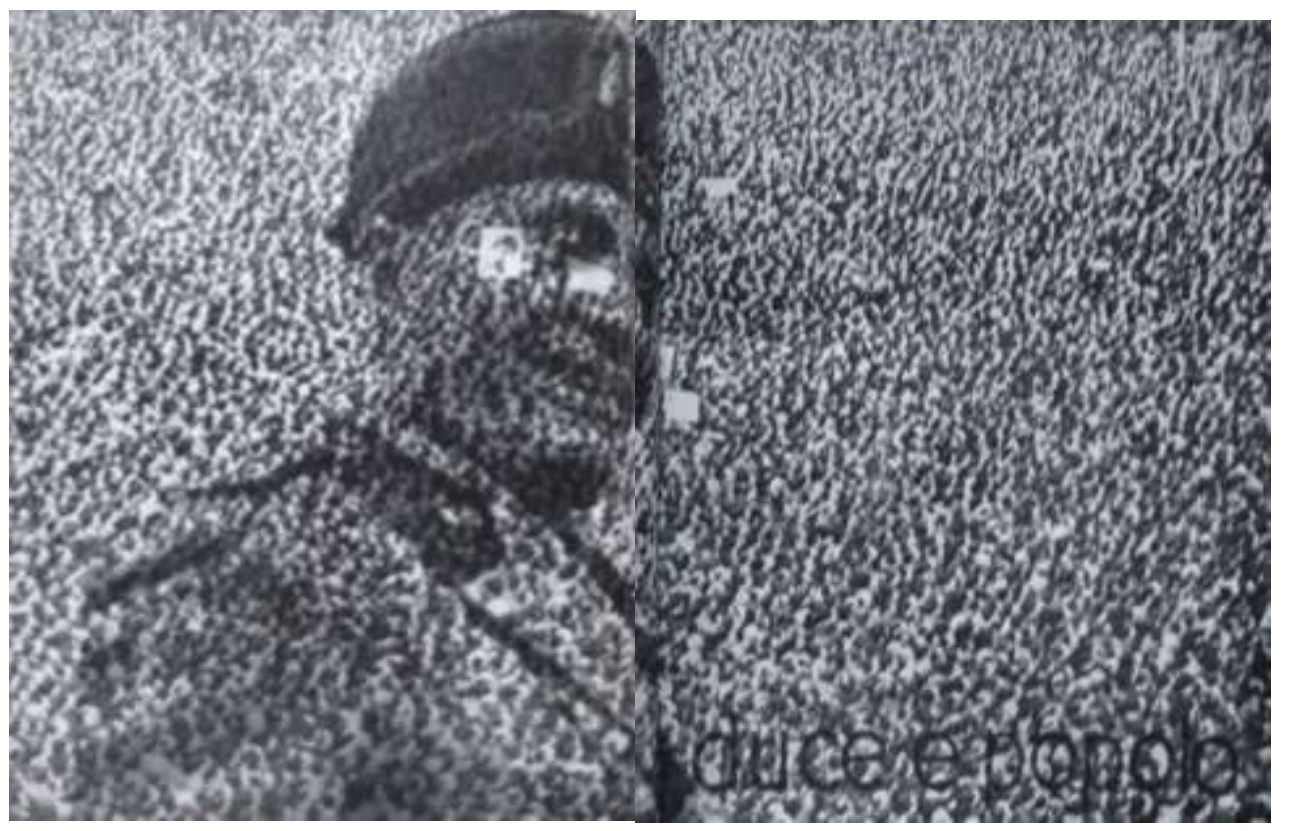

Figure 14. Duce and People, from the Photobook Il Fascio Primogenito, Curated by the Milanese Fascist Party, Officine Grafiche Esperia, Milano, 1938, Private Collection

The pages in which the message is expressed only through combination of visual elements and typographic solutions are new and daring compared to the solutions previously analyzed. The story of the delivery of the wedding rings, when the Italian population was invited to incur war costs by donating their wedding rings, is told through a single image. Here, the typographical elements are arranged in the void of the sheet as a building in the atmosphere and transform white into a concrete and active element. The story takes place through an assembly of a few elements, endowed with great iconic strenght (once again, 
for example, the hand appears) while the colours serve to emphasize parts that surround the events of 8 December 1935 (Figure 15).

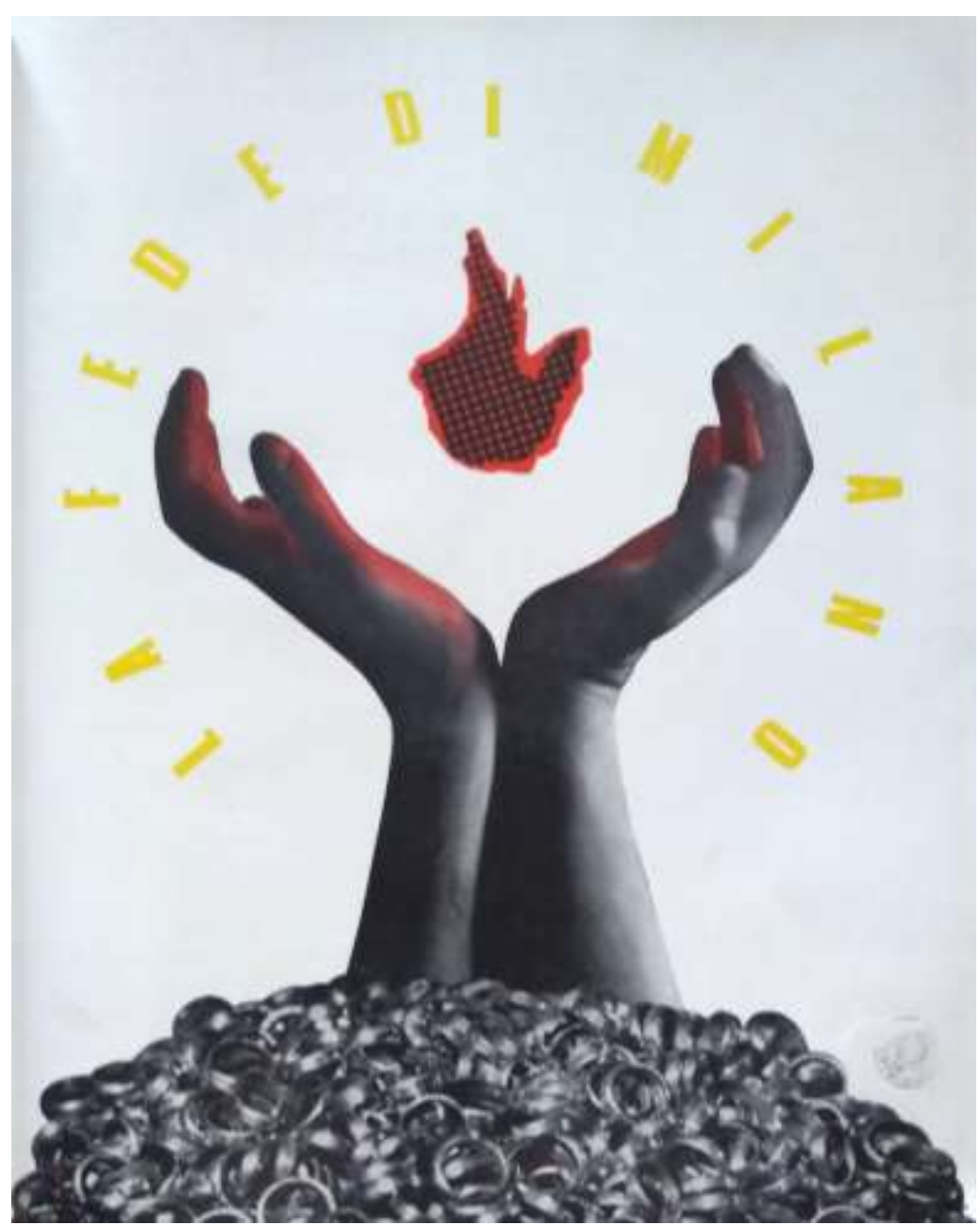

Figure 15. Example of Layout from the Photobook Il Fascio Primogenito, Curated by the Milanese Fascist Party, Officine Grafiche Esperia, Milano, 1938, Private Collection

\section{Conclusion}

The study of Fascist photobooks revealed the role played by avant-garde languages in regime's Mythopoeia, an aspect that is often overlooked. For the historiography, in fact, the image of Fascism is that of the L.U.C.E. Institute, whose modesty is also confirmed by Gabriele D'Autilia, the main connoisseur of archival material: he admits that this type of photography "will not succeed in creating the incisive ideological alphabet of the Nazi image (real and idealized at 
the same time), whose own clarity is able to create a mythical suspense." 34 In propaganda photobooks, instead, aberrations of perspective, details and chiaroscuro effects are used to generate symbols, that is, visible and concrete objects of a reality, which is that of Fascist era. Moreover, these symbols are made up from the internalization of rules and group norms, making individual behavior correspond to the government motion.

The study also demonstrates that, within the photographic books of fascist propaganda, the relationship between text and image does not involve in a slavish dictatorship of the word on the image - as claimed by Roland Barthes, one of the first scholas to introduce a reflection on the nature of information transmitted by photography ${ }^{35}$ - but gains new connotations, characterized by a drasting reduction of writing in favour of a narrative autonomy of the iconic datum. In this way, the photographic reproduction, though enclosed by a written text, becomes the protagonist of the layout. The latter also participate to the trasmission of the information, enhancing the significance of the phototext.

The variability of the relationship between text and photography is an incisive strategy to trigger the transformation of fascist utopia into myth. As Pelayo argues, the utopia is a "rational construction", which "shows us how things are with a mathematical analysis," 36 while myth is "hope in what is to come, that is, fulfilment of the promise of history." 37 Thus, when the presumed objectivism (utopia) of the image is sublimated in strongly suggestive forms (myth), the observer's critical sense is no longer protected from all the possible artifices of the framing.

[...] what has been conceived as utopia, once it has been adopted by the masses passing from reason to emotion, can change its structure and its function untili $t$ become myth, since at the bottom of every utopia there is always a mythical idea. ${ }^{38}$

So, in this sophisticated device of persuasion, the image has above all a mythpoietic function, rather than a cultural and informative one. Modern photographic language is used to describe Mussolini's Italy, proud of its traditions and its history but also projected towards a new idea of progress: glimpses deeply rooted in common image are put near photographs in which the Italian landscape is a reclaimed nature crowded by chimneys and skyscrapers.

In this way, Roland Barthes' perspective is completely turned upside down. The French philosopher, in fact, describes photography as an "emanation of the

34. D'Autilia, Storia della Fotografia in Italia dal 1939 a Oggi (Turin: Einaudi, 2012), 206207.

35. Cf. R. Barthes, "Il Messaggio Fotografico, 1961," in L'Ovvio e l'Ottuso. Saggi Critici III, 5-21 (Turin: Einaudi, 1985), 5-21.

36. M. G. Pelayo, Miti e Simboli Politici (Turin: Borla, 1970), 35.

37. Ibid.

38. Ibid, 37. 
referent:" ${ }^{39}$ therefore, it is bound to the real object to which it refers. In regime propaganda devices, instead, the truth of photography is radically questioned: it offers a representation, in which the real is present only as a quotation or fragment. So, within the propaganda photobooks the photography opens up a self-referential, a hyper-real space, completely detached from the referent. Hyperreality doesn't represent anything: it presents.

\section{Bibliography}

AA.VV. Campo Grafico: 1933-1939 [Graphic Field: 1933-1939.] Milan: Electa, 1983.

AA.VV. Campo Grafico: La Sfida della Modernità [Graphic Field: The Challenge of Modernity.] Milan: Centro Studi Grafici di Milano, 2003.

Anonymous. "Il Volto della Nuova Italia" [The Face of New Italy.] Il Corriere Fotografico 30, no. 6 (1933): 31.

Anonymous. "Libri Fotografici” [Photographic Books.] Natura 8, no. 10 (1936): 27.

Anonymous. “Italia Imperiale" [Imperial Italy.] L'Ufficio Moderno 13, no. 7 (1937): 341.

Baltzer, N. Die Fotomontage im Faschistischen Italien. Aspekte der Propaganda unter Mussolini [The Photomontage in the Fascist Italy. Aspects of Propaganda under Mussolini.] Berlin: de Gruyter, 2015.

Barthes, R. "Il Messaggio Fotografico, 1961" [The Photographic Message, 1961.] In L'Ovvio el'Ottuso. Saggi Critici III, 5-21. Turin: Einaudi, 1985.

Barthes R. La Camera Chiara. Nota sulla Fotografia [Camera Lucida. Note on Photography.] Turin: Einaudi, 2003.

Bellavista, M. “Per un'Arte Fotografica al Tempo di Mussolini” [For a Photographic Art at the Time of Mussolini.] Galleria 14, no. 4 (1936): 4-7.

Boggeri, A. "La Fotografia alla Fiera di Milano" [Photography at the Milan Fair.] Natura 5, no. 3 (1932): 43-48.

Campany, D. "The Photobook: What's in a name?" The Photobook Rewiew. Aperture 7 (2014): 2-7.

Chiabrando, M. "Guido Modiano e la Nuova Tipografia Italiana" [Guido Modiano and the New Italian Typography.] In TDM5: Grafica Italiana, edited by G. Camuffo, M. Piazza and C. Vinti. Mantova: Corraini; Milan: Triennale Design Museum, 2012.

Chinellato, A. and C. G. Noventa. La Superficie Bianca. Il Prodotto Editoriale tra Storie e Progetti [The White Surface. The Editorial Product between Stories and Projects.] Padova: Libreria Universitaria, Padova, 2013.

Chiti, G. "Il Libro Fotografico in Italia dal 1940 al 1980" [The Photographic Book in Italy from 1940 to 1980.] AFT. Rivista di Storia e Fotografia 19, no. 37/38 (2003): 78-111.

Colombo, F. Libri Giornali e Riviste a Milano: Storia delle Innovazioni nell'Editoria Milanese dall'Ottocento ad Oggi [Books, Newspapers and Magazines in Milan: A History of Innovations in Milanese Publishing from the Nineteenth Century to the Present.] Milan: Abitare Segesta, 1998.

39. Barthes, La Camera Chiara. Nota sulla Fotografia (Turin: Einaudi, 2003), 81. 
D'Autilia, G. 2005. Il Fascismo senza Passione. L'Istituto L.U.C.E. [Fascism without Passion. The L.U.C.E. Institution.] In L'Italia del XX secolo. Le Fotografie e la Storia, edited by G. De Luna, G. D'Autilia and L. Criscenti, 91-116. Turin: Einaudi, 2005.

D'Autilia, G. Storia della Fotografia in Italia dal 1939 a Oggi [The History of Photography in Italy from 1939 to Date.] Turin: Einaudi, 2012.

D'Autilia, G. L.U.C.E. The Italian Collective Consciousness. Rome: Rai Edu and L.U.C.E. Institution, 2014.

Dradi, C. Millenovecentotrentatre: Nasce a Milano la Grafica Moderna [One Thousand Nine Hundred Thirty-Three: Modern Graphics is Born in Milan.] Milan: Ufficio Stampa del Comune di Milano, 1973.

Gomez Palacio, B. and A. Vit. Graphic Design Referenced: A Visual Guide to the Language, Applications and History of Graphic Design. Beverly: Rockport, 2010.

Isnenghi, M. "Iconografia della Stampa Fascista" [Fascist Press Iconography.] Belfagor: Rassegna di Varia Umanità 32, no. 3 (1977): 344-352.

L.U.C.E. L'Italia Fascista in Cammino [Fascist Italy on its Way.] Rome: Istituto Poligrafico dello Stato, 1932.

Mannucci, S. La Fotografia dell'Istituto L.U.C.E. Storia e Critica [L.U.C.E. Insitution Photography. History and Critique.] s.n., s.l., 2014.

Massani, G. La Sua Terra [His Land.] Bergamo: Istituto Italiano d'Arti Grafiche, 1936.

Meggs, P. B. A History of Graphic Design. New York: J. Wiley \& Sons, 1998.

Milanese Fascist Party (curated by). Il Fascio Primogenito. Milan: Officine Grafiche Esperia, 1938.

Modiano, G. “Fotografia 1931” [Photography 1931.] L'Industria della Stampa 3, no. 6 (1931): 101-102.

Modiano, G. “Fotografia 1931” [Photography 1931.] Campo Grafico 2, no. 12 (1934): 274-275.

Morgagni, M. (Ed.) Imperial Italy XIV E. F. Milan: La Rivista Illustrata del Popolo d'Italia, 1937.

Müller, J. and J. Wiedemann. Graphic Design: 1890-1959. Volume 1. Köhln: Taschen, 2019.

Mussolini, B. Vita di Arnaldo [Life of Arnaldo.] Milan: Popolo d'Italia, 1932.

Ottaviani, G. Le Veline del Minculpop: Aspetti della Propaganda Fascista [The Govern Statements: Aspects of Fascist Propaganda.] Milan: Todariana, 1999.

Paoli, S. 1999. "L'Annuario di Domus del 1943" [The 1943 Domus Yearbook.] In A Paolo Costantini. Fotografo e Collezionista (Dedicated to Paolo Costantini, Photographer and Collector), edited by T. Serena, 99-128. Pisa: Scuola Normale Superiore, Pisa, 1999.

Parr, M. and G. Badger. The Photobook: A History. Volume I. London: Phaidon, 2004.

Patti, G., L. Sacconi and G. Ziliani. Fotomontaggio: Storia, Tecnica, Estetica [Photomontage: History, Technique, Aesthetics.] Milan: Mazzotta, 1979.

Pelayo, M. G. Miti e Simboli Politici [Political Myths and Symbols.] Turin: Borla, 1970.

Pellegrini G. "La Fotografia e il Libro Moderno" [Photography and the Modern Book.] Galleria 15, no. 1 (1936): 3.

Pellittieri, G. and O. Rossi. “Campo Grafico” [Graphic Field.] Homo Faber 20 (1953): 1-8.

Piazza, C. Pho-to-Booked. Un Libro con le Foto di 107 Libri con le Foto [Pho-to-Booked. A Book with the Photos of 107 Books with the Photos.] Rimini: Digitalprint, 2016.

Ponti, G. "Discorso Sull'arte Fotografica" [Discourse on Photographic Art.] Domus 5, no. 53 (1932): 285-288.

Rich. "Bibliografia Fotografica” [Photo Bibliography.] Il Corriere Fotografico 36, no. 2 (1939): 41-43. 
Rich. "Finalmente un Libro" [Finally a Book.] Il Corriere Fotografico 36, no. 4 (1939): 98.

Rossi, A. "Scopi Semplici" [Simple Pourposes.] Campo Grafico 1, 1 (1933): 3.

Russo, A. Fascismo in Mostra [Fascism on Show.] Rome: Editori Riuniti, 1999.

Starace, A. "Editorial." Gioventù Fascista 3, no. 3 (1933): 1.

Tranfaglia, N. La Stampa del Regime, 1932-1943. Le Veline del Minculpop per Orientare l'Informazione [The Regime's Press, 1932-1943. The Government Statements to Guide the Information.] Milan: Bompiani, 2005.

Vinti, C. "Modiano e la 'Mostra Grafica' alla VII Triennale" [Modiano and the Graphic Exhibition at the VII Triennale.] Progetto Grafico 4-5 (2006): 50-63.

Von Graefe, A. Il Nuovo Volto d'Italia [The New Face of Italy.] Milan: Mondadori, 1933. 
